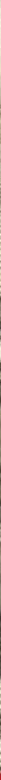

$\underset{s}{2}$

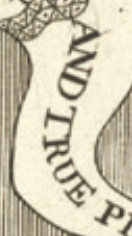

aif a
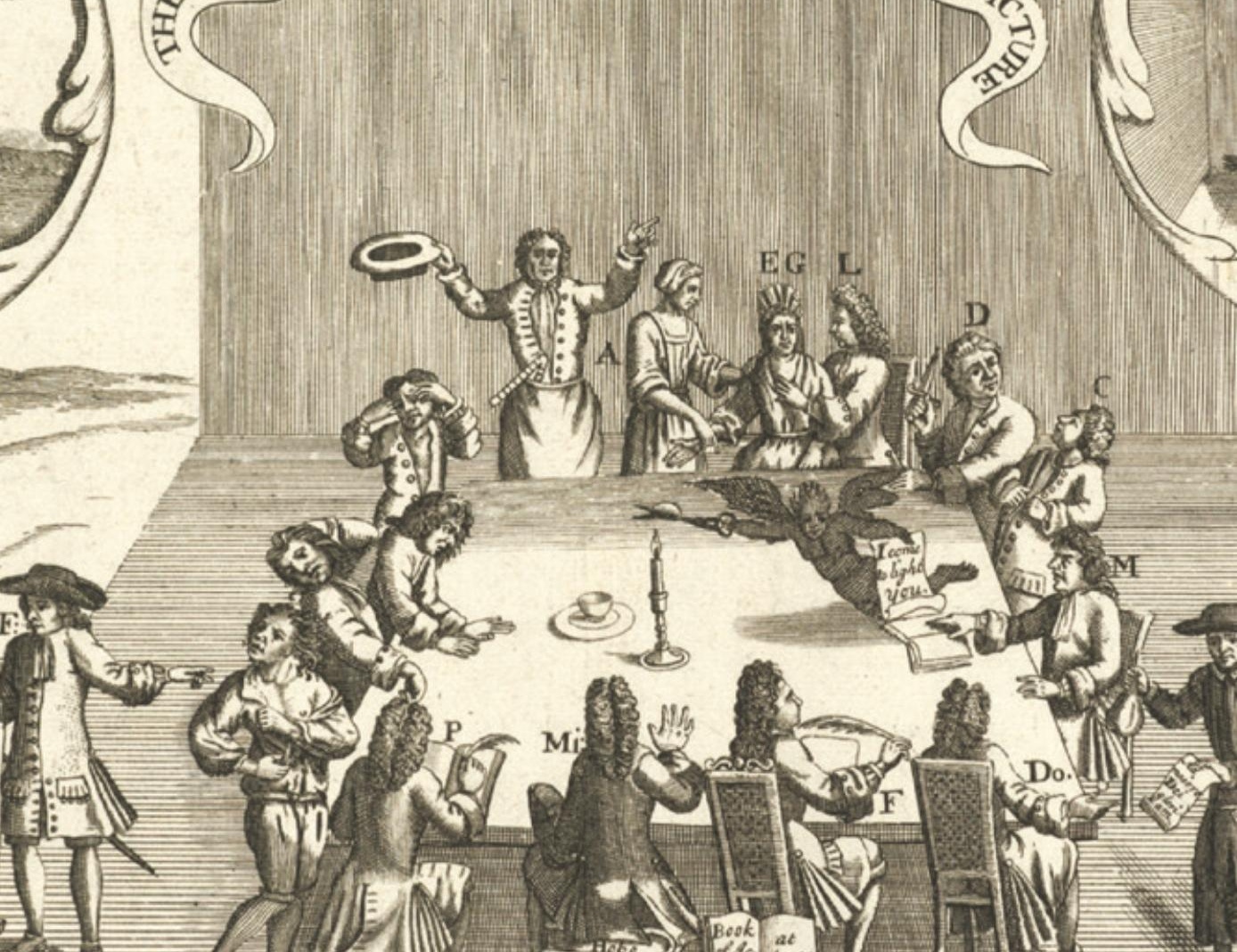

\title{
ENIIGITENING ENTHUSIASM
}

PROPIECY AND RELIGIOUS EXPERIENCE IN EARLY EIGITEENTI-CENTURY ENGLAND 


\section{Blank page}




\section{Enlightening enthusiasm}

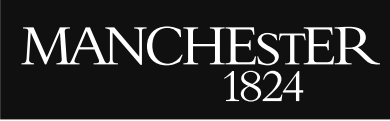

Manchester University Press 


\section{Blank page}




\title{
Enlightening enthusiasm
}

\section{Prophecy and religious experience in early \\ eighteenth-century England}

\author{
Lionel Laborie
}

Manchester University Press 
Copyright $\odot$ Lionel Laborie 2015

The right of Lionel Laborie to be identified as the author of this work has been asserted by him in accordance with the Copyright, Designs and Patents Act 1988.

Published by Manchester University Press

Altrincham Street, Manchester M1 7JA

www.manchesteruniversitypress.co.uk

British Library Cataloguing-in-Publication Data

A catalogue record for this book is available from the British Library

Library of Congress Cataloguing-in-Publication Data applied for

ISBN 9780719089886 hardback

First published 2015

The publisher has no responsibility for the persistence or accuracy of URLs for any external or third-party internet websites referred to in this book, and does not guarantee that any content on such websites is, or will remain, accurate or appropriate.

Typeset by Out of House Publishing 